\title{
Faithful History or Unreliable History: Three Debates on the Historicity of the Xia Dynasty
}

\author{
Chen Minzhen 陳民鎮 \\ Assistant Researcher, Beijing Language and Culture University, China \\ chenminzhizhen@163.com
}

Translated by Carl Gene Fordham

\begin{abstract}
Three debates on the historicity of the Xia dynasty [ca. 2100-1600 BCE] have occurred, spanning the 1920 s and 1930s, the late 1900 s and early 200os, and recent years. In the first debate, Gu Jiegang 顧頡剛 [1893-1980], Wang Guowei 王國維 [1877-1927], and Xu Xusheng 徐旭生 [1888-1976] pioneered three avenues for exploring the history of the Xia period. The second debate unfolded in the context of the Doubting Antiquity School [Yigupai 疑古派] and the Believing Antiquity School [Zouchuyigu 走出疑古] and can be considered a continuation of the first debate. The third debate, which is steadily increasing in influence, features the introduction of new materials, methods, and perspectives and is informed by research into the origins of Chinese civilization, a field that is now in a phase of integration.
\end{abstract}

\section{Keywords}

doubting antiquity - faithful history - unreliable history - Xia dynasty

The question of the historicity of the Xia dynasty [ca. 2100-1600 BCE] may be considered from two perspectives. First, did the Xia dynasty exist? Second, on the whole, are the accounts relating to the Xia dynasty as recorded in ancient texts reliable? This perspective tends to center upon the veracity of the historical events involving Yu the Great 大禹. Different people at different stages have placed different emphases on these two perspectives. With the increasing range of archeological materials currently available, the historical and archeological community in China generally no longer calls the existence of the Xia 
dynasty into question and acknowledges that the lineage and legends of the dynasty have a historical background, with the point of contention turning to a concrete understanding of Xia culture from an archeological perspective. However, there remain scholars in Europe and the United States who do not acknowledge the Xia dynasty as having a faithful historical record, ${ }^{1}$ which affects understanding of the Xia dynasty by Chinese people both in and outside academia.

The debate surrounding the historicity of the Xia dynasty has unfolded in two major stages. The first stage involved the rise of the Doubting Antiquity School [Yigupai 疑古派] during the 1920s and 1930s, during which the veracity of historical figures in the Xia dynasty such as Yu the Great and other historical events became the main focal point. The second stage witnessed the publication of The Cambridge History of Ancient China, the completion of the Xia-Shang-Zhou Chronology Project [Xia-Shang-Zhou duandai gongcheng 夏商周斷代工程], and the discovery of the Suigongxu 遂公䀅 ritual bronze vessel, during which time the potential existence of the Xia dynasty and whether Erlitou culture [Erlitou wenhua 二里頭文化] was related to it became critical issues. The first debate accompanied the development of the Doubting Antiquity School and the advent of modern archeology in China, while the second debate accompanied a dispute between the Doubting Antiquity School and those who doubted the doubters. A third debate, which has taken place in recent years and is rapidly gaining momentum, is a miniature of the rise and fall in the ideological trend of research into ancient Chinese history. The differing views regarding the methods and historical records brought out in this debate are worth summarizing and reflecting on.

\section{Different Avenues, Same Destination: the First Debate and the Three Methods}

In 1923, Gu Jiegang 顧頴剛 [1893-1980] said in his letter "Talking About Ancient History with Mr. Qian Xuantong," "I believe Yu 禹 may have been a kind of animal that was cast on the Nine Tripod Cauldrons [jiuding 九鼎].... [By the time the folklore] had been handed down to later times, Yu had morphed into a

1 B. Karlgren, "Legends and Cults in Ancient China," Bulletin of the Museum of Far Eastern Antiquities 18 (1946): 199-365; S. Allan, "The Myth of the Xia Dynasty," Journal of the Royal Asiatic Society 116, no. 2 (1984); A. Birrell, Chinese Mythology: An Introduction (Baltimore: Johns Hopkins University Press, 1993). The scholars in Europe and the United States mentioned here refer mainly to those in sinological circles. Although sinologists educate people in the West on all kinds of knowledge about Chinese, they do not represent the views of other Western academics, such as those in archeology and anthropology. 
real human ruler."2 This piece of correspondence marks the beginning of the first debate, and $\mathrm{Gu}$ joined the polemic with Liu Shanli 劉掞㴝 [1899-1935], Hu Jinren 胡堇人 [1886-1935], Liu Yizheng 柳詒徵 [1880-1956], and others. ${ }^{3}$ In the letter, Gu classifies Yu as a deified animal, taking the view that Yu as recorded in the history books of antiquity was a product of mythology. Gu later abandoned this notion, deciding to place the myth of Yu the Great in the context of the various southern peoples, arguing that the legend of Yu originated in the middle period of the Western Zhou [1046-771 вCE] dynasty. He went on to contend that originally Yu was unrelated to the Xia dynasty and that the link only formed midway through the Warring States Period [475-221 BCE.$^{4}$ He later placed $\mathrm{Yu}$ in the context of the western regions of the Central Plain. Although Gu changed his position on Yu's legendary origins numerous times, he insisted throughout that Yu was a mythological figure. Gu did not question the objective existence of the Xia dynasty; on the contrary, he argued that "the existence of Xia cannot be doubted"5 and during his collaboration with Tong Shuye 童書業 [1908-1968] on Verifying the History of the Xia ${ }^{6}$ argued that the history of the Xia dynasty is made up of a collection of myths. By making use of historical materials of and after the Warring States Period, Gu then

2 Gu Jiegang 顧頡剛, “Yu Qian Xuantong xiansheng lun gushi shu 與錢玄同先生論古史 書 [Talking about Ancient History with Mr. Qian Xuantong]," Dushu zazhi 讀書雜誌, no. 9 (1922).

3 Liu Shanli 劉掞㢣 wrote "Da Gu Jiegang jun yu Qian Xuantong xiansheng lun gushi shu de yiwen 答顧頴剛君〈與錢玄同先生論古史書〉的疑問 [Responding to Questions Raised by Gu Jiegang's “Talking about Ancient History with Mr. Qian Xuantong']” and “Taolun gushi zaizhi Gu xiansheng 討論古史再質顧先生 [Talking about Ancient History with Mr. Gu]," Hu Jinren 胡堇人 wrote “Du Gu Jiegang xiansheng lun gushi shu yihou 讀顧頡剛先 生論古史書以後 [Impressions of Mr Gu Jiegang's “Talking about Ancient History'],” Liu Yizheng 柳詒徵 wrote "Lun yi Shuowen zhengshi bi xianzhi Shuowen zhi yili 論以〈說文〉 證史必先知〈說文〉之誼例 [When Using the Shuowen to Verify Historical Records One Must First Know Some Relevant Examples from the Shuowen]," and Gu Jiegang 顧頴岡 wrote “Da Liu Hu liang xiansheng shu 答劉胡兩先生書 [Responding to Letters from Mr. Liu and Mr. Hu]" and “Taolun gushi da Liu Hu er xiansheng 討論古史答劉胡二先生 [Discussing Ancient History with Mr. Liu and Mr. Hu]," and the response to it in "Da Liu Yimou xiansheng 答柳翼謀先生 [Responding to Mr. Liu Yimou (a.k.a. Liu Yizheng)]." All these articles were in Gu Jiegang, Gushi bian 古史辨 (Shanghai: Shanghai guji chubanshe, 1982).

4 Gu Jiegang, "Taolun gushi da Liu-Hu er xiansheng," Dushu zazhi, no. 12 (1922), 1-4.

5 Gu Jiegang, “Chunqiu Zhanguo shi jiangyi di yi bian (minzu yu jiangyu) 春秋戰國史講義 第一編（民族與疆域） [Lecture Notes on the Histories of the Spring and Autumn and Warring States Periods, part 1: Peoples and Territories]," in Gu jiegang gushi lunwenji 4 顧頡 剛古史論文集 4 [A Collection of Gu Jiegang's Writings on Ancient History, vol. 4] (Beijing: Zhonghua shuju, 2011): 114 .

6 Gu Jiegang, Gu Jiegang quanji yi 1 顧頡剛全集 1 [Complete Works of Gu Jiegang, vol. 1] (Beijing: Zhonghua shuju, 2010). 
summarized the changes that occurred in the mythology surrounding the Xia dynasty. Although Gu did not explicitly deny the existence of the Xia dynasty, he believed that the figures and events of the period referred to in available records were mostly fabricated by later generations, thereby implying that the history of the Xia is unreliable. Later, Chen Mengjia 陳夢家 [1911-1966] in The Mythology and Sorcery of the Shang Dynasty stated that the Xia and Shang [ca. 1600-1046 в CE] dynasties shared the same lineage, ${ }^{7}$ while Yang Kuan 楊寬 [1914-2005] in On the Xia contended that the history of the Xia dynasty was a fabrication of the Zhou [1046-256 BCE] people, ${ }^{8}$ categorically stating that the history of the Xia is unreliable. Commenting on the views of Chen and Yang, Gu said,

Taking note that the Xia and Shang periods are close to each other and that not one record of the Xia period has been found in the tens of thousands of pieces of oracle bone script available, the doubts of the two gentlemen are not unreasonable.... While I lack the evidence needed to confirm that the Xia period must have existed, it is difficult to assert that it did not exist. ${ }^{9}$

Thus, while Gu did not completely deny the Xia dynasty may have existed, he expressed understanding of the doubts held by Chen and Yang.

While the Doubting Antiquity School tended to concern itself with deconstructing historical materials, Wang Guowei 王國維 [1877-1927] dedicated himself to reconstructing methods and materials. In 1925, Wang taught a course at Tsinghua University called "New Criticisms of Ancient History" [Gushixinzheng 古史新證]. Much of what he taught was deliberately directed at the Doubting Antiquity School. In his lecture notes, Wang argued that, although ancient Chinese history and legends are intermingled, "legends often form the basis of historical facts,"10 and thus documentary records cannot be easily negated. Wang paid particular attention to analyzing the value

7 Chen Mengjia 陳夢家, “Shangdai de shenhua yu wushu 商代的神話與巫術 [The Mythology and Sorcery of the Shang Dynasty]," Yanjing xuebao 燕京學報, no. 20 (December 1936).

8 Yang Kuan 楊寬, “Shuo Xia 說夏 [On the Xia],” in Zhongguo shanggushi daolun 中國上 古史導論 [Introduction to Chinese Ancient History] (Shanghai: Shanghai renmin chubanshe, 2016).

9 Gu Jiegang, “Anyu 按語 [Comments]," in Gushi bian, 291.

10 Wang Guowei 王國維, Gushixinzheng: Wang Guowei zuihou de jiangyi 古史新證一王國 維最後的講義 [New Criticisms of Ancient History: Notes on Wang Guowei's Last Lecture] (Beijing: Qinghua daxue chubanshe, 1997), 1. 
of historical materials and in his notes listed credible excavated and received texts. However, Wang's research methodology is more noteworthy. He proposed a "dual-evidence approach" [erchong zhengju fa 二重證據法] based on foundations laid by his predecessors in which excavated texts and received texts could be cross-verified and interpreted. Wang had previously argued for the credibility of the Shang dynasty lineage based on oracle bone inscriptions, suggesting that

With the certainty of the Shang-Zhou lineage, it is in turn possible to infer the certainty of the lineage of the Xia dynasty.... That being the case, although some of the events in Chinese antiquity as recorded in the classics have not yet been subjected to the dual-evidence approach, we cannot simply erase them from the history books. ${ }^{11}$

Wang believed that the credibility of the Shang-Zhou lineage meant that the credibility of the Xia dynasty lineage could also be inferred. This inference, while not unreasonable, is methodologically lacking. Discussion on the Xia dynasty in New Criticisms of Ancient History is limited to chapter 2, "Yu." This demonstrates both a lack of supporting historical sources related to the Xia period and that Yu was a point of contention at the time. Wang also verified the credibility of the legend of Yu by examining the gui 篮 (a bowl-shaped ritual bronze vessel) of the Duke of Qin [Qin gong 秦公] and the $b o$ 鎛 (a large bronze bell with a flat lip) and zhong 鍾 (another type of bronze bell) of the Marquis of Qi [Qi hou 齊侯]. He observed that

There was an understanding that the lineage of the Spring and Autumn Period [ca. 770-ca. $476 \mathrm{BCE}$ ] was made up of the two major polities of Qi [1044-221 BCE $]$ in the east and Qin [770-207 BCE] in the west. There was no disbelief that $\mathrm{Yu}$ the Great was a ruler in antiquity. Thereafter came Tang 湯 [са. 1675-1646 вСE], and then the later kings of the Shang dynasty. 12

Here one may see specifically how the dual-evidence approach may be applied. In a similar disagreement over Gu's sympathy for the Doubting Antiquity School, Xu Xusheng 徐旭生 [1888-1976] took another route to investigate the history of the Xia. With the encouragement of Fu Sinian 傅斯年 [1896-1950], Li Ji 李濟 [1896-1979], and others, major archeological breakthroughs were made at the Yinxu 殷墟 [Ruins of Yin] site. It was a demonstration to the

11 Wang Guowei, Gushixinzheng, 52-53.
12 Wang Guowei, Gushi xinzheng, 6. 
general public about how ancient history could be reconstructed by means of archeology. Meanwhile, Xu began to examine the legendary period in Chinese history before the Shang dynasty. In his view, $\mathrm{Gu}$ "went too far and his views became less credible. As a result, I do not believe his conclusion to be correct."13 Beginning in 1938, Xu endeavored to "complete a comprehensive collation of the legendary sources of ancient Chinese history," culminating in his renowned work The Legendary Period in Ancient Chinese History, in which he discussed at length the various methods and materials used in ancient history research and explained what he saw as the five serious offenses committed by the Doubting Antiquity School, including the misuse of arguments from silence (i.e., using an absence of data in documents as evidence for an argument). ${ }^{14}$ In 1959, he proposed the areas of activity of the Xia people on the basis of ancient documentary sources in an attempt to fill in the gap of knowledge regarding their geographic location. This heralded the beginning of Xia culture archeology and may be seen as an extension of the first debate.

In the first debate, $\mathrm{Gu}$ Jiegang, Wang Guowei, and Xu Xusheng laid the foundation for three different avenues for investigating the history of the Xia period. Under the ideological influence of Gu's Doubting Antiquity School, the credibility of Xia history was subjected to unprecedented skepticism, which continues to this day. Wang paved the way for the study of new evidence- that is, making use of excavated texts to verify ancient history —and established the basic theme for pre-Qin history research in China at the time. Xu pioneered the use of archeological discoveries to investigate the history of the Xia period, and the Erlitou site that he discovered was acknowledged in the Chinese archeological field as the most important source for researching Xia culture. The avenues for academic research opened by Gu Jiegang, Wang Guowei, and $\mathrm{Xu}$ Xusheng did not develop one after the other but, rather, complemented and propelled one another, thereby laying the foundation for what would become a truly integrated field of research. In the end, their avenues led to the same destination, with a shared focus on using excavated texts and archeology to reconstruct ancient history. However, when it came to specific types of research, such as handling documentary sources and examining the link between ancient texts and archeology, the avenue that each of them pioneered developed different tendencies, whose divergences found their way into the second debate.

\footnotetext{
13 Xu Xusheng 徐旭生, Zhongguo gushi de chuanshuo shidai (xiudingben) 中國古史的傳 說時代（修訂本） [The Legendary Period in Ancient Chinese History] (Beijing: Wenwu chubanshe, 1985), 1.

14 Xu Xusheng, Zhongguo gushi de chuanshuo shidai, 23-27.
} 
In 1999, The Cambridge History of Ancient China, edited by M. Loewe and E. L. Shaughnessy, ${ }^{15}$ was published, and it can be considered a summary of ancient Chinese history research as understood by European and American scholars. The book takes the position that the Shang dynasty was China's first dynasty. In response, Xie Weiyang 謝維揚 made the following statement:

This position is not unusual in Western sinological circles. Indeed, we have heard it so often that we can practically recite it in our sleep. However, The Cambridge History of Ancient China adopted this standpoint with the promise of providing a commonly accepted synthesis based on an exhaustive discussion of the latest pre-Qin material available at the end of the 1990s. This is of extraordinary significance, because if this book aims to provide a commonly accepted synthesis, then the blood, sweat, and tears of Chinese scholars over the past decade that brought about countless achievements in Xia period research will become a joke, and many Chinese scholars in the field will lose all sense of direction and not know how to get back on the right track. ${ }^{16}$

The "blood, sweat, and tears" that Xie refers to here are the archeological findings arrived at via the avenue pioneered by $\mathrm{Xu}$ Xusheng. Beginning in the second half of the twentieth century, field archeology achieved a series of breakthroughs, and with the support of Zou Heng 鄒衡 [1927-2005], Li Boqian 李伯謙, and other important scholars, mainstream academia in China gradually reached a consensus that the Erlitou site was the capital of the Xia dynasty, specifically even the Xia capital Zhenxun 卙陈 as recorded in historical sources, and that Erlitou culture and the culture of the late Xia period are closely related, for a number of reasons. Part (at least Phases I and II) of Erlitou culture overlaps with the chronology of the Xia period, the dates being earlier than, and exhibiting a particular relationship of inheritance with, the Shang dynasty, mainly Erligang culture [Erligang wenhua二里崗文化]. The culture also has a relatively expansive geographic reach, the basic elements of civilization, and the characteristics of a monarchy with a large area of rule. The Erlitou

15 M. Loewe and E. L. Shaughnessy, ed., The Cambridge History of Ancient China: From the Origins of Civilization to 221 B.C. (Cambridge: Cambridge University Press, 1999).

16 Xie Weiyang 謝維揚, "Shui shi Lushan zhenmianmu: Jianqiao Zhongguo shanggushi duhou 誰識盧山真面目一〈劍橋中國上古史〉讀後 [Who Can Recognize the True Face of Mount Lu? Impressions on The Cambridge History of Ancient China]," Wen hui bao 文匯報, April 21, 2001. 
site is located in the legendary area of activity of the Xia people and is laid out in a fashion that is typical of a royal capital. Based on this, sites such as Phase III of Wangwan culture [Wangwan sanqiwenhua 王灣三期文化] and the ruins of the Xinzhai period [Xinzhai qi yicun 新砦期遺存] were included within the scope of investigation. The recognition reached by the Xia-Shang-Zhou Chronology Project at the end of the twentieth century was largely informed by these understandings, and to some extent they may be read as a summary of the development of Xia culture archeology since 1959.

The summaries proposed by Chinese and Western academia at the end of the century sparked a new debate, and, upon completion of the Xia-ShangZhou Chronology Project, a serious of direct confrontations ensued. Unlike in the first debate, although the facticity of Yu the Great received attention from scholars, ${ }^{17}$ the focal point of the discussion had already shifted to the question of whether the Xia dynasty existed. In the eyes of many scholars from Europe and the United States, significant doubts were raised as to whether the Xia dynasty had existed and whether Erlitou culture was intrinsically Xia culture, let alone deducing the chronology of the Xia period based on this. After the project was completed, the Far Eastern Economic Review and The New York Times published commentary on it, along with the views of a number of sinologists. The commentary not only denied the feasibility of the project in terms of scientific principles but also criticized the project in strong terms, accusing it of being a product of government will and nationalism. The veracity of Xia history was the first contentious and critical issue in the criticism of the project. After the project was completed, discussion among Chinese scholars was mainly limited to the significance of Xia culture and the particulars of its chronology. The existence of the Xia dynasty and the close relationship between Erlitou culture and Xia culture were arguably points of consensus and presupposition, but Western scholars were still conflicted as to whether the Xia dynasty had even existed.18

17 See Tan Jihe 譚繼和, “Xia Yu wenhua de xin tansuo: jinnian lai Xia Yu wenhua yanjiu shuping 夏禹文化的新探索一近年來夏禹文化研究述評 [New Explorations of Xia Yu Culture: Reviews on the Latest Research on Xia Yu Culture]," Zhonghua wenhua luntan 中華文化論壇, no.1 (2000).

18 See Liu Xing 劉星, "Quexi de duihua: Xia-Shang-Zhou duandai gongcheng yinqi de haiwai xueshu taolun jishi 缺席的對話: 夏商周斷代工程引起的海外學術討論紀 實 [An Absent Dialogue: Records of Overseas Academic Discussion on the Xia-ShangZhou Chronology Project]," Zhongguo wenwubao 中國文物報, June 6, 2001, 5. See also Chen Xingcan 陳星燦 and Liu Li 劉莉, “Xia-Shang-Zhou duandai gongcheng yinqi de wangshang taolun jishi 夏商周斷代工程引起的網上討論紀實 [Records of Online Discussion on the Xia-Shang-Zhou Chronology Project]," Gudai wenming yanjiu tongxun 古代文明研究通訊 9 (June 2001). 
Although it is often said that scholars outside China deny the existence of the Xia dynasty, sinologists cannot entirely represent the views of Western academics. What we call the field of sinology is not exactly a monolith either. For instance, a large number of Japanese scholars recognize the existence of the Xia dynasty and its relationship with Erlitou culture, and considerable divergence is seen in the views of Western sinologists. Upon completion of the Xia-Shang-Zhou Chronology Project, D. S. Nivison even quipped that scholars worldwide would want to see the report torn up. ${ }^{19}$ This spirited attitude is mainly a response to differences in points of view, considering that, apart from suggesting that Xia Jie 夏桀 is a fictional figure, on the whole he acknowledged the existence of the Xia dynasty, even proposing dates from the Yellow Emperor [Huangdi 黃帝] to the Xia, Shang, and Zhou dynasties. ${ }^{20}$ On the contrary, Nivison appears to place excessive faith in the records of ancient Chinese history. In Early China, Nivison and K. D. Pang published an article in which they claim that it is possible that neither Yu nor Yao 堯 are mythical figures, and thus a precise chronological history can be determined. ${ }^{21}$ As a former editor of Early China, Edward L. Shaughnessy expressed his opposition to the view in the article with its tentative acceptance of the veracity of Xia history, stating that he did not believe a chronology for the Xia period could be determined. ${ }^{22}$

The divergences in opinion on Xia history between Shaughnessy and Nivison took place at the beginning of the 1990s, more or less at the same time. At the International Symposium on Xia Culture held at the University of California, Los Angeles, in May 1990, the majority of non-Chinese archeologists acknowledged the existence of the Xia dynasty. However, S. Allan and M.V.Dryukovcontended that theXia dynasty cannot beverified. ${ }^{23}$ Allan believed that records on the Xia from the Zhou period were derived from Shang binary

19 E. Eckholm, "In China, Ancient History Kindles Modern Doubts," New York Times, November 10, 2000.

20 D. S. Nivison, The Riddle of the Bamboo Annals (Taipei: Airiti Press, 2009), 45.

21 D. S. Nivison and K. D. Pang, "Astronomical Evidence for the Bamboo Annals' Chronicle of Early Xia," Early China 15 (1990): 95.

22 E. L. Shaughnessy, "Wo yu Ni Dewei jiaoshou guanyu zaoqi Zhongguo biannian de bianlun: Ni Dewei wenji xu 我與倪德衛教授關於早期中國編年的辯論—〈倪德衛文 集〉序 [My Debate with Prof. Nivison on the Chronology of Early China: Foreword to the Nivison Annals]," trans. Cheng Yuhei 程羽黑, Zhonghua dushubao 中華讀書報, September 7, 2016, 9.

23 Wang Yuxin 王宇信, “Meiguo Xia wenhua guoji yantaohui ceji 美國夏文化國際研 討會'側記 [Notes on the International Symposium on Xia Culture Held in the United States]," Zhongguoshi yanjiu dongtai 中國史研究動態, no. 8 (1990). 
myths, echoing at a distance the views of Yang Kuan and Chen Mengjia, and there is no shortage of sinologists who share similar views. ${ }^{24}$ The differing views among overseas scholars such as S. Allan, D. W. Pankenier, and Ikeda Suetoshi were further expressed at the International Conference on Xia and Shang Culture held in Luoyang in September 1991..$^{25}$ Scholars who refused to acknowledge the history of the Xia mainly approached the issue from a sinological background; however, academics outside China with archeological expertise were more likely to accept the findings of Chinese scholars on the history of this period. The willingness of foreign academics to recognize research on the Xia by Chinese scholars depended not only on methodology and historical sources but also on how well they understood the development of archeology in China, which in turn was bound up with their academic background.

The debate regarding the history of the Xia period at the beginning of the century was not confined to interactions between scholars in and outside China but extended to Chinese academia. Acquainted with Western theories on archeology, Chen Chun 陳淳 wrote a series of treatises expressing his suspicion that the history of the Xia was fabricated by later generations and that because no writing from the Xia period had been discovered, preconceived notions on this issue cannot be tolerated. Instead, he argued that the issue must be investigated independently from an archeological perspective and that any archeological research from China that uses overstated sources, has a weak theoretical foundation, or persists with outdated archeological methods must be subject to severe criticism. ${ }^{26}$ Academics such as Fang Yousheng 方西生

24 D. N. Keightley, "The Bamboo Annals and Shang-Chou Chronology," Harvard Journal of Asiatic Studies 38, no. 2 (1978); S. Allan, The Shape of the Turtle: Myth, Art and Cosmos in Early China (Albany: State University of New York, 1991), 57-73; R. L. Thorp, China in the Early Bronze Age: Shang Civilization (Philadelphia: University of Pennsylvania Press, 2006), 57-61.

25 Hu Zhenyu 胡振宇, “Shi nian lai Xia-Shang shi yanjiu de huigu yu zhanwang: Zhongguo Xia Shang wenhua guoji xueshu yantaohui ji 十年來夏商史研究的回顧與展望一中 國夏商文化國際學術研討會記 [Looking Back on Ten Years of Research into the Xia and Shang Periods: Notes on the International Conference on Xia and Shang Culture Held in China]," Shixue yuekan 史學月刊, no. 2 (1992).

26 Chen Chun 陳淳 and Gong Xin 壟辛, "Erlitou, Xia yu Zhongguo zaoqi guojia yanjiu二 里頭、夏與中國早期國家研究 [Research into Erlitou, Xia and Early Chinese States],” Fudan xuebao (Shehui kexue ban) 復旦學報（社會科學版）, no. 4 (2004); Chen Chun, Wenming yu zaoqi guojia tanyuan: Zhongwai lilun, fangfa yu yanjiu zhi bijiao 文明與早 期國家探源: 中外理論,方法與研究之比較 [Exploring the Origins of Civilization and Early States: A Comparison between Chinese and Foreign Theories, Methods, and Research] (Shanghai: Shanghai shudian chubanshe, 2007), 504-509. 
and Shen Changyun 沈長雲 issued prompt responses. ${ }^{27}$ Shen then penned a number of articles attempting to prove the existence of the Xia dynasty, ${ }^{28}$ arguing, "The Xia period is both legendary and historical fact." ${ }^{29}$ Other academics such as Zhang Guoshuo 張國碩 and Du Yong 杜勇 subjected the theory that denies the existence of the Xia dynasty to a systematic discussion. ${ }^{30}$ Chen Chun's denial of Xia history was mostly on account of his background in archeology and anthropology. His debate with Shen Changyun may be characterized as an interdisciplinary dialogue. Although Chen's focus on theory and reflection may overlook or even disregard the value of documentary sources, the issues he raised are worthy of consideration.

The discovery of the Suigongxu ritual bronze vessel in 2002 caused the discussion of whether the Xia dynasty existed to shift to the question of whether Yu the Great existed. Its inscription "the heavens instructed Yu to spread the

27 Fang Yousheng 方酉生, "Luelun Erlitou yizhi de wenhua xingzhi: Jian yu Zhongguo wenming yu guojia tanyuan de sikao deng wen shangque 略論二里頭遺址的文化性 質一兼與〈中國文明與國家探源的思考〉等文商榷 [On the Cultural Nature of the Erlitou Site and 'Tracing the Origins of Chinese Civilization and State']," Dongnan wenhua 東南文化, no. 3 (2003); Shen Changyun 沈長雲, "Xiadai shi duzhuan de ma: yu Chen Chun xiansheng shangque 夏代是杜撰的嗎一與陳淳先生商榷 [Is the Xia Period a Fabrication? A Discussion with Mr. Chen Chun]," Hebei shifan daxue xuebao (zhexue shehui kexue ban) 河北師範大學學報 (哲學社會科學版), no. 3 (2005).

28 Shen Changyun, "Lun Yu zhi hongshui zhenxiang jian lun Xia shi yanjiu zhu wenti 論禹 治洪水真象兼論夏史研究諸問題 [On the Veracity of Yu's Taming of the Floods and Some Issues Pertaining to Research into the History of the Xia]," Xueshu yuekan 學術月 刊, no. 6 (1994); Shen Changyun, "Guanyu Xiadai guojia chansheng de ruogan lilun yu shizheng wenti 關於夏代國家產生的若干理論與實證問題 [Some Theoretical and Evidentiary Issues Regarding State Formation in the Xia Period]," Zhongyuan wenhua yanjiu 中原文化研究, no. 1 (2015).

29 Shen Changyun and Zhang Weilian 張渭蓮, Zhongguo gudai guojia qiyuan yu xingcheng yanjiu 中國古代國家起源與形成研究 [Research on the Origins and Formation of the Ancient Chinese State] (Beijing: Renmin chubanshe, 2009), 188.

30 Zhang Guoshuo 張國碩, “Zhoudai duzhuan Xia wangchao shuo kaobian 周代杜撰“夏王 朝說”考辨 [Testing the Theory That the Xia Dynasty Was Fabricated in the Zhou Period]," Zhongyuan wenwu 中原文物, no. 3 (2010); Zhang Guoshuo, "Lun Xia wangchao cunzai de yiju 論夏王朝存在的依據 [Evidence for the Existence of the Xia Dynasty], Z Zhongguo lishi wenwu 中國歷史文物, no. 4 (2010); Zhang Guoshuo, "Shixi Xia wangchao fouding shuo xingcheng de yuanyin 試析 “夏王朝否定說” 形成的原因 [A Tentative Analysis on the Contributing Factors behind Xia-Dynasty Denial]," Huaxia kaogu 華夏考古, no. 4 (2010); Du Yong 杜勇, “Guanyu lishi shang shifou cunzai Xiachao de wenti 關於歷史上 是否存在夏朝的問題 [On the Question of the Existence of the Xia Dynasty], Tianjin shifan daxue xuebao (shehui kexue ban) 天津師範大學學報 (社會科學版), no. 4 (2006). 
earth, collapse the mountains, and deepen the rivers" ${ }^{31}$ reignited interest in the historical figure. If the gui of the duke of Qin and the bo and zhong of the marquis of Qi proved that "ordinary people living during the Spring and Autumn Period acknowledged that before the Shang there was the Xia and that Yu was the progenitor of the Xia,"32 then the discovery of the Suigongxu pushes the widespread circulation of the legend of Yu the Great forward to the middle of the Western Zhou dynasty. Gu Jiegang once stated that the legend of Yu the Great did not form until the middle of the Western Zhou dynasty. The discovery of the Suigongxu called Gu's theory into question, because the legend of Yu the Great was already common knowledge among the people midway through the Western Zhou dynasty, and it had already circulated before this time. As pointed out by Li Xueqin 李學勤 [1933-2019], the Suigongxu provides the earliest evidence of a cultural object mentioning the legend of Yu the Great devising a flood prevention system, ${ }^{33}$ while some scholars have deduced on this basis that Yu the Great was a real individual. Qiu Xigui 歨錫圭 has argued on the basis of the Suigongxu vessel inscription that in relatively early legends it is indeed said that Yu was ordered by Shangdi 上帝 (the sky deity in Chinese mythology) to tame the floods, supporting Gu's theory that Yu was a spiritual being that had little to do with Emperors Yao and Shun 舜, ${ }^{34}$ a view that is somewhat similar to that of Huang Yongnian 黃永年. ${ }^{35}$ Some scholars believe that tian 天 refers to Emperor Shun, ${ }^{36}$ though Guo Yongbing 郭永秉

31 Li Xueqin 李學勤, “Lun Suigongxu ji qi zhongyao yiyi 論举公盨及其重要意義 [On the Suigongxu and Its Significance]," Zhongguo lishiwenwu 中國歷史文物, no. 6 (2002), 5 .

32 Guo Moruo 郭沫若, "Zhongguo gudai shehui yanjiu Xia Yu de wenti 中國古代社會研 究.夏禹的問題 [Research into Ancient Chinese Society: The Problem of Yu of Xia]," in Guo Moruo quanji: lishi bian 1 郭沫若全集.歷史編 1 [Complete Works of Guo Moruo: History Volume, vol. 1] (Beijing: Renmin chubanshe, 1982), 306.

33 Li, "Lun Suigongxu ji qi zhongyao yiyi."

34 Qiu Xigui 装錫圭, “Xin chutu xianqin wenxian yu gushi chuanshuo 新出土先秦文獻 與古史傳說 [Newly Excavated Pre-Qin Texts and the Legends of Ancient History]," in Qiu Xigui xueshu wenji 5 装錫圭學術文集 5 [Academic Writings of Qiu Xigui, vol. 5] (Shanghai: Fudan daxue chubanshe, 2012), 257.

35 Huang Yongnian 黃永年, “Ping 'Zouchu yigu shidai' 評〈走出疑古時代〉 [A Review of 'Departing from the Times of Doubting Antiquity']," in Jinian Gu Jiegang xiansheng danchen yi bai yi shi zhou nian lunwenji 紀念顧頴剛先生誕辰一百一十週年論文集 [Proceedings of the Celebration of Mr. Gu Jiegang's noth Birthday], ed. Institute of History at the Chinese Academy of Social Sciences and the Department of History at Sun Yat-sen University (Beijing: Zhonghua shuju, 2004), 130.

36 Jiang Linchang 江林昌, Zhongguo shanggu wenming kaolun 中國上古文明考論 [Examining the Ancient Civilization of China] (Shanghai: Shanghai jiaoyu chubanshe, 2005), 237 . 
has a different understanding of this. ${ }^{37}$ However, it is not that the explanation proposed by Qiu is completely doubtless. As pointed out by Li Rui 李銳, "Tianming is, at least from the point of view of the people who lived during the Western Zhou dynasty, only a kind of concept. It cannot be claimed that all those who carry out tianming are deities." ${ }^{38}$ Scholars such as Xie Weiyang and Shen Changyun hold similar views. ${ }^{39}$ Guo Yongbing believes that the legends of Tiandi instructing King Wen of Zhou 周文王 and Tiandi instructing Yu are essentially different, and thus a parallel cannot be drawn between them. ${ }^{40}$ The issues associated with the Suigongxu vessel that began to surface during the first debate touched upon how to interpret the relationship between Tiandi and the images of figures such as Yu the Great and King Wen of Zhou.

The debate surrounding the potential existence of the Xia dynasty and that of the historicity of $\mathrm{Yu}$ the Great have similar points of contention, and it is unlikely that these issues can be reconciled. By comparison, the views of Chinese scholars during the second debate were more uniform, and the scope of the debate went global, reflecting a head-on collision between the different paradigms of Chinese and Western academia. Moreover, more materials were available for discussion during the second debate, mainly the findings of archeological excavations over the past half-century, which would have

37 Guo Yongbing 郭永秉, Dixi xin yan: Chu di chutu Zhanguo wenxian zhong de chuanshuo shidai gu diwang xitong yanjiu 帝系新研: 楚地出土戰國文獻中的傳說時代古帝王 系統研究 [New Research on the Lineage of the Three Sovereigns and Five Emperors: Using Texts of the Warring States Period Excavated from Chu Territory to Examine the Ancient Rulers of the Legendary Period of Ancient Chinese History] (Beijing: Beijing daxue chubanshe, 2008), 40.

38 Li Rui 李銳, “Erchong zhengjufa de jieding ji guize tanxi ‘二重證據法”的界定及規則探 析 [An Analysis of the Definitions and Parameters of the Dual-Evidence Approach]," Lishi yanjiu 歷史研究, no. 4 (2012).

39 Xie Weiyang 謝維揚, “Gushu chengshu he liuchuan qingkuang yanjiu de jinzhan yu gushi shiliaoxue gainian: wei jinian gushi bian di yi ce chuban 80 zhou nian er zuo 古書成書和 流傳情況研究的進展與古史史料學概念: 為紀念〈古史辨〉第一冊出版 80 週 年而作 [Progress Made in Research into the Formation and Circulation of Ancient Texts and the Concept of Ancient Chinese Documentology: In Commemoration of the 8oth Anniversary of the First Volume of Gushi Bian]," Wen shi zhe 文史哲, no. 2 (2007); Shen Changyun, "Suigongxu ming yu Yu zhi hongshui wenti zai taolun 㸚复公昷銘與禹治洪 水問題再討論 [On the Suigongxu Inscription and Yu's Taming of the Floods]," Guoxue xuekan 國學學刊, no. 1 (2014).

$40 \quad$ Guo Yongbing, "Zhe shi yi ge genben de taidu wenti: Xin chutu xianqin wenxian yu gushi chuanshuo daodu 這是一個根本的態度問題: 〈新出土先秦文獻與古史傳說〉 導讀 [All about Attitude: A Guide to 'Newly Excavated Pre-Qin Texts and the Legends of Ancient History']," in Guwenzi yu guwenxian lunji xubian 古文字與古文獻論集續 編 [A Continuation of the Collection of Works on Ancient Writing and Ancient Documents] (Shanghai: Shanghai guji chubanshe, 2015). 
been unimaginable during the first debate. If it can be claimed that the first debate opened three avenues for academic research, then the second debate can be characterized as a dispute between the Doubting Antiquity School and the Believing Antiquity School [Zouchu yigu 走出疑古]. Li Xueqin proposed a "departure from the Age of Doubting Antiquity" [Zouchu yigu shidai 走出 疑古時代], ${ }^{41}$ which was challenged by some academics. ${ }^{42}$ It is noteworthy that scholars who supported the Doubting Antiquity School did not deny the existence of the Xia dynasty. This view is consistent with that of the Believing Antiquity School. On this point, the schools share common ground in facing opposition from academic circles outside China. However, they differ significantly in their positions on the question of whether Yu the Great was a real individual.

\section{In the Ascendant: the Rise of the Third Debate}

The first two debates on the historicity of theXia period can be seen as manifestations of what Li Xueqin terms "the big rethink on ancient texts" or "the reconstruction of classical studies" as put forth by Qiu Xigui. Essentially, these two debates were a reassessment of method and material, while the third debate was a continuation of the first. Li Xueqin drew on Wang Guowei's research method, Qiu Xigui emulated Gu Jiegang's critical spirit, and the archeological field continued its exploration of Xia culture via the avenue initially opened up by Xu Xusheng. During the second debate, these three avenues became more integrated. The divergences had already been reduced, at least in the Chinese academic community. After the second debate, discussion on the historicity of the Xia period had subsided somewhat. Progress in this field would have been unlikely before the advent of new materials, methods, and perspectives. In fact, the third debate had already begun, and was accompanied by research into the origins of Chinese civilization, a field that had just begun its consolidation. Meanwhile, new materials, methods, and perspectives deepened the

\footnotetext{
41 Li Xueqin 李學勤, “Zouchu yigu shidai 走出疑古時代 [Departing from the Age of Doubting Antiquity]," Zhongguo wenhua 中國文化, no. 7 (1992).

42 Liu Qiyu 劉起釬, “Guanyu zouchu yigu shidai wenti 關於'走出疑古時代, 問題 [On Departing from the Age of Doubting Antiquity]," Chuantong wenhua yu xiandaihua 傳統 文化與現代化, no. 4 (1995); Lin Yin 林澐, "Zhen gai zouchu yigu shidai ma: dui dangqian Zhongguo gudianxue quxiang de kanfa 真該走出疑古時代嗎? 對當前中國古典學 取向的看法 [Should We Really Depart from the Age of Doubting Antiquity? My Views on the Direction Chinese Classical Studies Is Currently Headed]," Shixue jikan 史學集刊, no. 3 (2007).
} 
discussion. It was not an after-effect of the second debate; rather, a more indepth discussion came about in changed circumstances. Evidently, the third debate is in the ascendant and continues to deepen.

In 2016, Science published the report "Outburst Flood at 1920 BCE Supports Historicity of China's Great Flood and the Xia Dynasty," detailing the findings of a Sino-American research team headed by Wu Qinglong 吳慶龍.43 The report attempted to verify the occurrence of major flooding during the age of $\mathrm{Yu}$ the Great from a geological perspective. It considered the Jishixia 積石峽 dam break on the upper reaches of the Yellow River in Qinghai Province the trigger of the event and sought to determine the chronological relationship between the flooding and Erlitou culture, with the aim of deducing the historicity of the Xia period. The report also returned scholarly attention to the major flooding during the time of $\mathrm{Yu}$ 虞 and Xia, and raised the issue of authenticity regarding the history of the Xia as a subject of discussion again. Although the report drew upon research undertaken by archeological workers on the Lajia 喇家 and Erlitou sites, archeologists in China were generally skeptical of the report, mainly because it overlooked new developments in carbon-14 dating and inferred that Erlitou culture is not the earliest form of Xia culture. Scholars such as Zhang Jingwei 張經緯, Shen Changyun, and Guo Jingyun 郭靜雲 made their own criticisms. ${ }^{44}$ In the assessment of these skeptical academics, there can be no doubt that the Xia dynasty existed and that $\mathrm{Yu}$ the Great tamed the floods; what they take issue with is the space and time in which the flood taming occurred, as suggested by the article. Allan extends her argument, claiming that the Xia originated in myth, while acknowledging the indisputable possibility of a connection between the Xia dynasty and Erlitou. ${ }^{45}$

43 Wu Qinglong, Zhao Zhijun, Liu Li, et al., "Outburst Flood at 1920 вCE Supports Historicity of China's Great Flood and the Xia Dynasty," Science 353, no. 6299 (2016).

44 Zhang Jingwei 張經緯, “Da Yu he qianli zhi wai de hongshui 大禹和千里之外的洪水 [Yu the Great and the Flood Thousands of Miles Away]," Wenhui bao, Aug 12, 2016, 2; Guo Jingyun 郭靜雲, “Jishixia hongshui yu Da Yu zhishui wuguan 積石峽洪水與大禹治水 無關 [No Relationship between the Jishixia Flood and the Introduction of Flood Control by Yu the Great]," Zhongguo shehui kexue bao 中國社會科學報, November 8, 2016, 6; Shen Changyun, “Zai lun Yu zhi hongshui jian ji Xia shi zhu wenti 再論禹治洪水兼及夏 史諸問題 [Another Discussion of Yu's Taming of the Floods and Some Issues Pertaining to the History of the Xia]," Zhongguo shehui kexue bao, November 8, 2016, 6.

45 S. Allan, "The Jishi Outburst Flood of 1920 BCE and the Great Flood Legend in Ancient China: Preliminary Reflections," Journal of Chinese Humanities 3, no. 1 (2017); S. Allan [艾蘭], "Dui xiyuanqian 1920 nian jishixia hongshui yu gudai zhongguo hongshui chuanshuo de chubu sikao 對西元前 1920 年積石峽洪水與古代中國洪水傳說的初步思考 [The Jishi Outburst Flood of 1920 BCE and the Great Flood Legend in Ancient China: Preliminary Reflections]," Wen shi zhe, no. 1 (2018). 
The report attracted such an immense response for two reasons: first, because of the particularly influential nature of Science; second, because the report adopted the methods of natural science, which undoubtedly would have been an avenue of considerable appeal for advocates of scientism. A conclusion that can be drawn here is that when documentary and archeological sources are interpreted in significantly different ways, the methods of natural or archeological science can be used to dispel doubts. Many scholars had already attempted to demonstrate the period and background of Yu's flood taming from the perspectives of climate and geography. Recently, some academics have argued that the background for Yu's flood taming was the extreme rainfall on the Loess Plateau circa 2000 ВСE, not the collapse of a barrier lake as claimed by the report. ${ }^{46}$ Other researchers completely refuted the theoretical underpinnings of the report. They contended that the formation and collapse of the barrier lake at Jishixia, the sudden deaths of ancient humans, as well as ancient earthquakes, all occurred independently of one another at different times, and that no major flooding took place circa 1920 BCE on the upper reaches of the Loess Plateau ${ }^{47}$ It is currently difficult to verify the historicity of the Xia period by archeological means to a standard that satisfies public expectations because of restrictions in subjective and objective conditions.

At around about the same time as the report appeared, Cai Zhemao 蔡哲茂 published the article "New Evidence on the Existence of the Xia Dynasty: Mentions of Xiyi in the Shang-Dynasty Oracle Bone Inscriptions," which integrated the "Yinzhi” 尹至 and “Yin'gao" 尹誥 passages in the Qinghua bamboo slips [Qinghua jian 清華簡], along with material from Shang-dynasty oracle bone inscriptions, to argue that Xiyi 西邑 was the capital of the Xia dynasty at the very beginning. However, in the oracle bone inscriptions, it had been transformed into a specter representing the former kings of the Xia dynasty, which demonstrates the existence of the Xia dynasty.48 In the "Yinzhi" passage, the polity or capital of Xia was referred to as Xiyi, known in the “Yin'gao" passage as Xiyixia 西邑顐[夏]. Before this time, Cai had already

46 Liangcheng Tan, Chuan-Chou Shen, Yanjun Cai, et al., "Great Flood in the Middle-Lower Yellow River Reaches at 4000 a BP Inferred from Accurately-Dated Stalagmite Records," Science Bulletin 63, no. 4 (2018).

47 Dong Guanghui 董廣輝 et al., "Lajia yizhi shiqian zaihai yu huanghe dahongshui wuguan 喇家遺址史前災害與黃河大洪水無關 [Disasters at the Lajia Site Have Nothing to Do with the Yellow River Flood]," Zhongguo kexue: diqiu kexue 中國科學: 地球科學 [Science in China (Earth Sciences)], no. 4 (2018).

48 Cai Zhemao 蔡哲茂, “Xia wangchao cunzai xinzheng, shuo yin buci de xiyi 夏王朝存在 新證一說殷卜辭的西邑 [New Evidence on the Existence of the Xia Dynasty: Mentions of Xiyi in the Shang-Dynasty Oracle Bone Inscriptions]," Zhongguo wenhua 中國文化 [Chinese Culture] 44 (October 2016). 
stated that in oracle bone inscriptions featuring worship of Moxi 妹喜 (the first wife of Xia Jie) and Yi Yin 伊尹 (a minister in the early Shang dynasty), 茂 is read as mò 妹, which might refer to Moxi. Thus it can be verified that Moxi was a historical figure and that the Xia preceded the Shang. ${ }^{49}$ Hu Houxuan 胡厚宣 linked Xiyi with Xiyixia, as recorded in the oracle bone inscriptions in the Shang dynasty, ${ }^{50}$ while Cai explicitly stated that Xiyi refers to the Xia dynasty. Regarding the geographic location of these two terms, Shen Jianhua 沈建華 believes that Xiyi refers to the settlement of Shangcheng at Yanshi 偃師, Xibo 西毫, and that Xiyi could not have gone beyond the Yi 伊 and Luo 洛 Rivers. ${ }^{51}$ Although the mainstream view is that the capital of the last ruler of the Xia dynasty was located in the Yiluo 伊洛 region (and thus at Erlitou, Yanshi), this claim is particularly dubious in light of chronological, cultural, and documentary data. ${ }^{2}$ The Xiyixia explanation originates in the "Ziyi" 緇衣 chapter of The Book of Rites [Liji 禮記], in which the "Yin'gao" passage is cited, and later annotated by late-Han scholar Zheng Xuan 鄭玄 [127-200] as follows: "the capital of the Xia was to the west of Bo." In the "Speech of Tang" [Tangshi 湯誓] chapter in the Book of Documents [Shangshu 尚書], Kong Chuan 孔傳 says, “Jie's capital was at Anyi” [Jie du Anyi 桀都安邑]. In his work Collected Commentaries on the Book of Documents [Shu ji zhuan 書集傳], the scholar of the Southern Song [1127-1279] dynasty Cai Shen 蔡沈 [1167-1230] says, "The capital of the Xia, Anyi, was located to the west of Bo and thus was called Xiyixia." The theory that the ruins of the Xia are in southern Shanxi and that Anyi was the location of Jie's capital, though not explicitly supported by archeological evidence, is worth investigating.

The aforementioned newly excavated text Shang Shu 商書 part of the Book of Documents provides important clues as to the historical events that occurred during the Xia and Shang dynasties, while the "Houfu" 厚父 segment

49 Cai Zhemao, “Yiyin chuanshuo de yanjiu 伊尹傳說的研究 [The Study of Yi Yin's Legend]," in Zhongguo Shenhua yu chuanshuo xueshuyantaohui lunwenji 中國神話與傳 說學術研討會論文集 [Proceedings of Chinese Myths and Legends Symposium], ed. Li Yiyuan 李亦園 and Wang Qiugui 王秋桂 (Taibei: Hanxue yanjiu zhongxin, 1996), 274.

50 Hu Houxuan 胡厚宣, “Yin buci Zhong de shangdi he wangdi shang 殷卜辭中的上帝 和王帝（上）[Shangdi and Wangdi in the Shang-Dynasty Oracle Bone Inscriptions, part 1]," Lishiyanjiu 歷史研究, no. 9 (1959).

$5^{1}$ Shen Jianhua 沈建華, “Qinghua chujian yinzhi shiwen shijie 清華楚簡〈尹至〉釋 文試解 [Explanation of the Yinzhi Article's Translation in the Qinghua Bamboo Slips],” Zhongguoshiyanjiu 中國史研究, no.1 (2011).

52 Chen Minzhen 陳民鎮, “Qinghuajian yiyin zhupian yu shangtang judi ji fajie luxian kao 清華簡伊尹諸篇與商湯居地及伐桀路線考 [The Study of Yi Yin Articles in Qinghua Bamboo Slips and Shangtang Residence and Attacting Jie's Route]," Guangxi shifan daxue xuebao 廣西師範大學學報, no. 2 (2018). 
of the fifth edition of the Qinghua bamboo slips may be part of the Xia shu 夏 書 [The Book of Xia Dynasty]. ${ }^{53}$ After the publication of "Houfu," some believe it is in the Zhou shu 周書 [The Book of Zhou Dynasty], others the Shang shu. Although scholars disagree on how the passage should be interpreted, it is nevertheless an important source on the history of the Xia. For example, the beginning of the text mentions the dredging of the rivers by Yu the Great, and this wording can be cross-referenced with the Suigongxu inscription. The passage also refers to Xia kings such as Qi 啟 and Kong Jia 孔甲, which is somewhat inconsistent with older interpretations, especially those pertaining to the image and position of Kong Jia. ${ }^{54}$ Guo Yongbing has argued that "Houfu" is a relatively early ancient text that explicitly speaks of a relationship between the $\mathrm{Yu}$ and Xia periods, while $\mathrm{Gu}$ Jiegang once suspected that this relationship did not emerge until much later and thus needs to be revised. ${ }^{55}$ However, Gu maintained that in this passage Yu tamed the floods under the instructions of the Emperor of Heaven and not Emperors Yao and Shun, while still receiving divine orders to pacify the people and establish the kingdom of Xia. ${ }^{56}$ On this topic, Ning Zhenjiang 寧鎮疆 stated that if Yu and the Xia had a relationship, it should not be merely one of deification..$^{57} \mathrm{He}$ went on to claim that, while the Suigongxu inscription indicates that the taming of the floods by Yu the Great was performed under divine instruction, the concept that the ruling power of a monarch is endowed by the heavens is peculiar to ancient China and cannot be taken as evidence that Yu the Great was a godhead and not a human ruler.

Both advocates and skeptics of the historicity of the Xia period believe their points of view are supported by concrete evidence, while holding particular prejudices of varying degrees and looking upon the argument of the other side

53 Guo Yongbing, “Lun qinghuajian houfu yingwei xiashu zhiyipian 論清華簡〈厚父〉應 為〈夏書〉之一篇 ['Houfu' in the Qinghua Bamboo Slips Should Be Part of the Xia shu]," in Chutu wenxian 7 出土文獻 7 [Excavated Texts, vol. 7], ed. Qinghua daxue chugtu wenxian yanjiu yu baohu zhongxin 清華大學出土文獻研究與保護中心 (Shanghai: Zhongxi shuju, 2015).

54 Zhao Ping'an 趙平安, “Houfu de xingzhi jiqi yunhan de xiadai lishi wenhua 〈厚父〉的 性質及其藴含的夏代歷史文化 [The Nature of the Houfu Article and Its Historical and Cultural Characteristics of the Xia Dynasty]," Wenwu 文物, no. 12 (2014).

55 Guo Yongbing, "Lun qinghuajian houfu yingwei xiashu zhiyipian," 118.

56 Guo Yongbing, "Zhe shi yi ge genben de taidu wenti," 340.

57 Ning Zhenjiang 寧鎮疆, "Qinghuajian houfu tianjiang xiamin ju de guannian yuanliu yu bingongxu mingwen zaishi 清華簡〈厚父〉“天降下民’句的觀念源流與睎公 昷銘文再釋—兼說先秦民民本”思想的起源問題 [Origin of the Sentence “Tianjiang Xiamin' in the Houfu Article in the Qinghua Bamboo Slips' and the Reinterpretation of Inscriptions on Suigongxu: Also on the Origin of 'People-Based' Thought in the Pre-Qin Period]," in Chutu wenxian, 7: 117. 
with a certain amount of selectivity. The two sides are in a deadlock because neither has access to evidence that could provide a definitive answer. The main reason that the history of the Xia period has been so contentious is a lack of documentary sources. So, when new texts become available, they are naturally considered extremely valuable, with prime examples being excavated texts, such as the Qinghua bamboo slips. That being said, archeological science has provided new methods and data, and in the eyes of positivists, research findings arrived at using natural science methods would undoubtedly be more persuasive. Although new methods and historical materials contribute to the discussion of relevant issues, they cannot resolve the debate because of their respective flaws.

Although archeological science has provided new methods, and excavated texts have provided new materials, Li Min 李旻 has provided new perspectives. Since 2016, Li has published many important papers on the image of Xia in social memory, ${ }^{58}$ as well as his recent treatise Social Memory and State Formation in Early China ${ }^{59} \mathrm{Li}$ traced the history of the Xia from the perspective of social memory, emphasizing that descriptions of the space, time, and technology of the Xia civilization in pre-Qin records were heavily influenced by the political, social, and cultural transformations that occurred from the age of Longshan 龍山 to Erlitou. He also attempted to expand the scope of Xia culture research to provide more potential for exploring the history of the Xia from an archeological perspective. This may prove to be a more reasonable avenue of inquiry in light of the fact that breakthroughs in methods and materials are few and far between in this field.

Ding zhai yu ji: An Archeological Reconstruction of the True History of the Xia Period, by Sun Qingwei 孫慶偉, is yet another monograph published recently on Xia culture. ${ }^{60}$ Sun's use of the term "true history" [xinshi 信史] in the work's title is a clear indication of his position. The work is a significant accomplishment in the field of Xia culture research and is the product of recent research

$5^{8}$ Li Min 李旻, "Setting on the Ruins of Xia: Archaeology of Social Memory in Early China," in Social Theory in Archaeology and Ancient History: the Present and Future Counternarratives, ed. G. Emberling (Cambridge: Cambridge University Press, 2016); Li Min, “Chongfan xiaxu: shehui jiyi yu jingdian de fasheng 重返夏墟: 社會記憶與經典 的發生 [Returning to Xiaxu: Social Memory and Occurrence of the Classic]," Kaogu xuebao 考古學報, no. 3 (2017).

59 Li Min, Social Memory and State Formation in Early China (Cambridge: Cambridge University Press, 2018).

6o Sun Qingwei 孫慶偉, Ding zhai yu ji: Xiadai xinshi de kaoguxue chongjian 躳宅禹 跡: 夏代信史的考古學重建 [The Trace of the Yu in the Ding House: Archaeological Reconstruction of the True History of the Xia Dynasty] (Beijing: Sanlian shudian, 2018). 
on the origins of Chinese civilization, a field that has recently entered a stage of integration. Its publication has also prompted new discussions on Xia culture and garnered widespread attention among the general public. Sun provided a narrow definition of Xia culture as consisting of the Longshan culture in Henan Province, including the Meishan type [Meishan leixing 煤山類型] and Wangwan type [Wangwan leixing 王灣類型], and Phases 1 to 4 of Erlitou culture, a definition that represents the current mainstream view in academia. Although these publications by Li Min and Sun Qingwei differ in their viewpoints, both stress the validity of archeology as a means of exploring Xia culture, while scholars such as Xu Hong 許宏 contend that the mainstream view should be reassessed. In his recent reexamination of the Erlitou site, $\mathrm{Xu}$ argued that the fact that there has not been an excavation of written materials featuring a writing system similar to that of the oracle bone script means that issues of clan and dynastic affiliation cannot be resolved. ${ }^{61}$ However, he did not simply designate the Xia period as referred to in the documentary sources as false history but, rather, proposed a number of reflections based on his understanding of the nature of the Erlitou site. In the view of Sun Qingwei, written material is not the only evidence that can verify the existence of the Xia dynasty. Sun believed that archeology has its own rationale in reconstructing the period and that the painstaking pursuit of evidence of a similar writing system reveals a lack of trust in, and understanding of, archeological research methodology. ${ }^{62}$ Neither received texts nor excavated texts enable the history of the Xia to be either completely verified or negated. That being said, as archeologists explore the culture of the Xia, they find themselves on increasingly steady footing. With the third debate currently in the ascendant, the depth and breadth of Xia culture research is bound to reach new heights.

\section{Works Cited}

Allan, S. "The Myth of the Xia Dynasty." Journal of the Royal Asiatic Society 116, no. 2 (1984): 242-56.

Allan, S. The Shape of the Turtle: Myth, Art and Cosmos in Early China. Albany: State University of New York Press, 1991.

\footnotetext{
61 Xu Hong 許宏, “Guanyu erlitou wei zaoshang duyi de jiashuo 關於二里頭為早商都邑 的假說 [Hypothesis That Erlitou Is the Capital of the Early Shang Dynasty]," Nanfang wenwu 南方文物, no. 3 (2015).

62 Sun Qingwei, Ding zhai yuji, 3.
} 
Allan, S. "The Jishi Outburst Flood of 1920 BCE and the Great Flood Legend in Ancient China: Preliminary Reflections." Journal of Chinese Humanities 3, no. 1 (2017): 23-34. Allan, S. [艾蘭]. Dui xiyuanqian 1920 nian jishixia hongshui yu gudai zhongguo hongshui chuanshuo de chubu sikao 對西元前 1920 年積石峽洪水與古代中國洪水 傳說的初步思考 [The Jishi Outburst Flood of 1920 BCE and the Great Flood Legend in Ancient China: Preliminary Reflections]. Wen shi zhe, no. 1 (2018): 23-27+165.

Birrell, A. Chinese Mythology: An Introduction. Baltimore: Johns Hopkins University Press, 1993.

Cai Zhemao 蔡哲茂. “Xia wangchao cunzai xinzheng, shuo yin buci de xiyi 夏王朝 存在新證：說殷卜辭的西邑 [New Evidence on the Existence of the Xia Dynasty: Mentions of Xiyi in the Shang-Dynasty Oracle Bone Inscriptions]." Zhongguo wenhua 中國文化 44 (October 2016): 47-51.

Cai Zhemao 蔡哲茂. “Yiyin chuanshuo de yanjiu 伊尹傳說的研究 [The Study of Yi Yin's Legend]." In Zhongguo shenhua yu chuanshuo xueshu yantaohui lunwenji 中國神話 與傳說學術研討會論文集 [Proceedings of Chinese Myths and Legends Symposium], ed. Li Yiyuan 李亦園 and Wang Qiugui 王秋桂, 243-276. Taibei: Hanxue yanjiu zhongxin, 1996.

Chen Chun 陳淳. Wenming yu zaoqi guojia tanyuan: Zhongwai lilun, fangfa yu yanjiu zhibijiao 文明與早期國家探源: 中外理論,方法與研究之比較 [Exploring the Origins of Civilization and Early States: A Comparison between Chinese and Foreign Theories, Methods, and Research]. Shanghai: Shanghai shudian chubanshe, 2007.

Chen Chun 陳淳 and Gong Xin 龔辛. "Erlitou, Xia yu Zhongguo zaoqi guojia yanjiu 二里頭, 夏與中國早期國家研究 [Research into Erlitou, Xia, and Early Chinese States].” Fudan xuebao (shehui kexue ban) 復旦學報 (社會科學版) 4 (2004): 82-91.

Chen Mengjia 陳夢家. "Shangdai de shenhua yu wushu 商代的神話與巫術 [The Mythology and Sorcery of the Shang Dynasty]." Yanjing xuebao 燕京學報, no. 20 (December 1936): 485-643.

Chen Minzhen 陳民鎮. “Qinghuajian yiyin zhupian yu shangtang judi ji fajie luxian kao 清華簡伊尹諸篇與商湯居地及伐桀路線考 [The Study of Yi Yin Articles in Qinghua Bamboo Slips and Shangtang Residence and Attacting Jie's Route]." Guangxi shifan daxue xuebao 廣西師範大學學報, no. 2 (2018): 1-11.

Chen Xingcan 陳星燦 and Liu Li 劉莉. “Xia-Shang-Zhou duandai gongcheng yinqi de wangshang taolun jishi 夏商周斷代工程引起的網上討論紀實 [Records of Online Discussion on the Xia-Shang-Zhou Chronology Project]." Gudai wenming yanjiu tongxun 古代文明研究通訊 9 (June 2001).

Dong Guanghui 董廣輝 et al. "Lajia yizhi shiqian zaihai yu huanghe dahongshui wuguan 喇家遺址史前災害與黃河大洪水無關 [Disasters at the Lajia Site Have Nothing to Do with the Yellow River Flood]." Zhongguo kexue: diqiu kexue 中國科 學: 地球科學 [Science in China (Earth Sciences)], no. 4 (2018): 467-475. 
Du Yong 杜勇. “Guanyu lishi shang shifou cunzai Xiachao de wenti 關於歷史上是否存 在夏朝的問題 [On the Question of the Existence of the Xia Dynasty]." Tianjin shifan daxue xuebao (shehui kexue ban) 天津師範大學學報（社會科學版), no. 4 (2006): 90-95.

Eckholm, E. "In China, Ancient History Kindles Modern Doubts." New York Times, November 10, 2000, A3.

Fang Yousheng 方西生. “Luelun Erlitou yizhi de wenhua xingzhi: Jian yu Zhongguo wenming yu guojia tanyuan de sikao deng wen shangque 略論二里頭遺址的文化性 質一兼與〈中國文明與國家探源的思考〉等文商榷 [On the Cultural Nature of the Erlitou Site and 'Tracing the Origins of Chinese Civilization and State']." Dongnan wenhua 東南文化, no. 3 (2003): 6-13.

Gu Jiegang 顧頡岡. “Taolun gushi da Liu Hu er xiansheng 討論古史答劉胡二先生 [Discussing Ancient History with Mr. Liu and Mr. Hu].” Dushu zazhi 讀書雜誌, no. 12 (1922): 1-4.

Gu Jiegang 顧頡剛. “Yu Qian Xuantong xiansheng lun gushi shu 與錢玄同先生論古史 書 [Talking about Ancient History with Mr. Qian Xuantong].” Dushu zazhi 讀書雜 誌, no. 9 (1922): 3-4.

Gu Jiegang 顧頡剛. Gushi bian 古史辨 [Ancient History Analysis]. Shanghai: Shanghai guji chubanshe, 1982.

Gu Jiegang 顧頴剛. Gu Jiegang quanji 1 顧頴剛全集 1 [Complete Works of Gu Jiegang, vol. 1]. Beijing: Zhonghua shuju, 2010.

Gu Jiegang 顧頡剛. “Chunqiu Zhanguo shi jiangyi di yi bian (minzu yu jiangyu) 春秋 戰國史講義第一編（民族與疆域） [Lecture Notes on the Histories of the Spring and Autumn and Warring States Periods, part 1: Peoples and Territories]." In Gu Jiegang gushi lunwenji 4 顧頴岡古史論文集 4 [A Collection of Gu Jiegang's Writings on Ancient History, vol. 4]. Beijing: Zhonghua shuju, 2011.

Guo Jingyun 郭靜雲. “Jishixia hongshui yu da Yu zhishui wuguan 積石峽洪水與大禹治 水無關 [No Relationship between the Jishixia Flood and the Introduction of Flood Control by Yu the Great]." Zhongguo shehui kexue bao 中國社會科學報, November $8,2016,6$.

Guo Moruo 郭沫若. “Zhongguo gudai shehui yanjiu Xia Yu de wenti 中國古代社會 研究 - 夏禹的問題 [Research into Ancient Chinese Society: The Problem of Yu of Xia]." In Guo Moruo quanji: lishi bian 1 郭沫若全集. 歷史編 1 [Complete Works of Guo Moruo: History Volume, vol. 1], 302-308. Beijing: Renmin chubanshe, 1982.

Guo Yongbing 郭永秉. “Lun qinghuajian houfu yingwei xiashu zhiyipian 7 論清華簡 〈厚父〉應為〈夏書〉之一篇 7 ['Houfu' in the Qinghua Bamboo Slips Should Be Part of the Xia shu, vol. 7]." In Chutu wenxian 出土文獻 [Excavated Texts], ed. Qinghua daxue chugtu wenxian yanjiu yu baohu zhongxin 清華大學出土文獻研究 與保護中心, 118-32. Shanghai: Zhongxi shuju, 2015. 
Guo Yongbing 郭永秉. “Zhe shi yi ge genben de taidu wenti: Xin chutu xianqin wenxian yu gushi chuanshuo daodu 這是一個根本的態度問題：〈新出土先秦文獻與古 史傳說〉導讀 [All about Attitude: A Guide to "Newly Excavated Pre-Qin Texts and the Legends of Ancient History']." In Guwenzi yu guwenxian lunji xubian 古文字與 古文獻論集續編 [A Continuation of the Collection of Works on Ancient Writing and Ancient Documents]. Shanghai: Shanghai guji chubanshe, 2015.

Guo Yongbing 郭永秉. Di xi xin yan: Chu di chutu Zhanguo wenxian zhong de chuanshuo shidai gu diwang xitong yanjiu 帝系新研: 楚地出土戰國文獻中的傳說時代 古帝王系統研究 [New Research on the Lineage of the Three Sovereigns and Five Emperors: Using Texts of the Warring States Period Excavated from Chu Territory to Examine the Ancient Rulers of the Legendary Period of Ancient Chinese History]. Beijing: Peking University Press, 2008.

Hu Houxuan 胡厚宣. “Yin buci Zhong de shangdi he wangdi shang 殷卜辭中的上帝和 王帝（上） [Shangdi and Wangdi in the Shang-Dynasty Oracle Bone Inscriptions, part 1]." Lishi yanjiu 歷史研究, no. 9 (1959): 23-51.

Hu Zhenyu 胡振宇. "Shi nian lai Xia-Shang shi yanjiu de huigu yu zhanwang: Zhongguo Xia-Shang wenhua guoji xueshu yantaohui ji 十年來夏商史研究的回顧與展望一中 國夏商文化國際學術研討會記 [Looking Back on Ten Years of Research into the Xia and Shang Periods: Notes on the International Conference on Xia and Shang Culture Held in China].” Shixue yuekan 史學月刊, no. 2 (1992): 107-10.

Huang Yongnian 黃永年. “Ping 'Zouchu yigu shidai' 評〈走出疑古時代〉 [A Review of Departing from the Times of Doubting Antiquity]." In Jinian Gu Jiegang xiansheng danchen yi bai yi shi zhou nian lunwenji 紀念顧頡剛先生誕辰一百一十週年論 文集 [Proceedings of the Celebration of Mr. Gu Jiegang's 11oth Birthday], ed. Institute of History at the Chinese Academy of Social Sciences 中國社會科學院 and the Department of History at Sun Yat-sen University 中山大學歷史系, 123-30. Beijing: Zhonghua shuju, 2004.

Jiang Linchang 江林昌. Zhongguo shanggu wenming kaolun 中國上古文明考論 [Examining the Ancient Civilization of China]. Shanghai: Shanghai jiaoyu chubanshe, 2005 .

Karlgren, B. "Legends and Cults in Ancient China." Bulletin of the Museum of Far Eastern Antiquities 18 (1946): 199-365.

Keightley, D. N. "The Bamboo Annals and Shang-Chou Chronology." Harvard Journal of Asiatic Studies 38, no. 2 (1978): 423-38.

Li Min 李旻. "Setting on the Ruins of Xia: Archaeology of Social Memory in Early China." In Social Theory in Archaeology and Ancient History: the Present and Future Counternarratives, ed. G. Emberling, 291-327. Cambridge: Cambridge University Press, 2016.

Li Min 李旻. “Chongfan xiaxu shehui jiyi yu jingdian de fasheng 重返夏墟: 社會記憶與 經典的發生 [Returning to Xia Xu: Social Memory and Occurrence of the Classic].” Kaogu xuebao 考古學報, no. 3 (2017): 287-316. 
Li Min 李旻. Social Memory and State Formation in Early China. Cambridge: Cambridge University Press, 2018.

Li Rui 李銳. “Erchong zhengjufa de jieding ji guize tanxi “二重證據法” 的界定及 規則探析 [An Analysis of the Definitions and Parameters of the Dual-Evidence Approach]." Lishiyanjiu 歷史研究, no. 4 (2012): 116-133+191-192.

Li Xueqin 李學勤. “Zouchu yigu shidai 走出疑古時代 [Departing from the Age of Doubting Antiquity]." Zhongguo wenhua 中國文化, no. 7 (1992): 1-7.

Li Xueqin 李學勤. “Lun Suigongxu ji qi zhongyao yiyi 論哸公湎及其重要意義 [On the Suigongxu and Its Significance]." Zhongguo lishi wenwu 中國歷史文物, no. 6 (2002): 4-12.

Lin Yin 林澐. "Zhen gai zouchu yigu shidai ma: dui dangqian Zhongguo gudianxue quxiang de kanfa 真該走出疑古時代嗎? 一對當前中國古典學取向的看法 [Should We Really Depart from the Age of Doubting Antiquity: My Views on the Direction in Which Chinese Classical Studies Is Currently Headed]." Shixue jikan 史學集刊, no. 3 (2007): 3-8, 25 .

Liu Qiyu 劉起釬. “Guanyu zouchu yigu shidai wenti 關於 “走出疑古時代” 問題 [On Departing from the Age of Doubting Antiquity]." Chuantong wenhua yu xiandaihua 傳統文化與現代化, no. 4 (1995): 22-28.

Liu Xing 劉星. “Quexi de duihua: Xia-Shang-Zhou duandai gongcheng yinqi de haiwai xueshu taolun jishi 缺席的對話：夏商周斷代工程引起的海外學術討論紀實 [An Absent Dialogue: Records of Overseas Academic Discussion on the Xia-ShangZhou Chronology Project]." Zhongguo wenwubao 中國文物報, June 6, 2001, 5 .

Loewe, M., and E. L. Shaughnessy, ed. The Cambridge History of Ancient China: From the Origins of Civilization to 221 B.C. Cambridge: Cambridge University Press, 1999.

Ning Zhenjiang 寧鎮疆. “Qinghuajian houfu tianjiang xiamin ju de guannian yuanliu yu bingongxu mingwen zaishi 清華簡〈厚父〉 ‘天降下民’ 句的觀念源流 與圈公公盆銘文再釋一兼說先秦 ‘民本” 思想的起源問題 [Origin of the Sentence 'Tianjiang Xiamin' in the Houfu Article in the Qinghua Bamboo Slips' and the Reinterpretation of Inscriptions on Suigongxu: Also on the Origin of 'People-Based' Thought in the Pre-Qin Period].” In Chutu wenxian 出土文獻 [Excavated Texts], ed. Qinghua daxue chugtu wenxian yanjiu yu baohu zhongxin 清華大學出土文獻研究 與保護中心, 7: 103-17. Shanghai: Zhongxi shuju, 2015.

Nivison, D. S. The Riddle of the Bamboo Annals. Taipei: Airiti Press, 2009.

Nivison, D. S., and K. D. Pang. "Astronomical Evidence for the Bamboo Annals' Chronicle of Early Xia." Early China 15 (1990): 87-95, 97-196.

Qiu Xigui 䒾錫圭. “Xin chutu xianqin wenxian yu gushi chuanshuo 新出土先秦文獻與 古史傳說 [Newly Excavated Pre-Qin Texts and the Legends of Ancient History]." In Qiu Xigui xueshu wenji 5 装錫圭學術文集 5 [Academic Writings of Qiu Xigui, vol. 5], 254-270. Shanghai: Fudan daxue chubanshe, 2012.

Shaughnessy, E. L. "Wo yu Ni Dewei jiaoshou guanyu zaoqi Zhongguo biannian de bianlun: Ni Dewei wenji xu 我與倪德衛教授關於早期中國編年的辯論—〈倪 
德衛文集〉序 [My Debate with Prof. Nivison on the Chronology of Early China: Foreword to the Nivison Annals]," translated by Cheng Yuhei 程羽黑. Zhonghua dushubao 中華讀書報, September 7, 2016, 9 .

Shen Changyun 沈長雲. “Zai lun Yu zhi hongshui jian ji Xia shi zhu wenti 再論禹治 洪水兼及夏史諸問題 [Another Discussion of Yu's Taming of the Floods and Some Issues Pertaining to the History of the Xia]." Zhongguo shehui kexue bao 中國社會科 學報, November 8, 2016, 6 .

Shen Changyun 沈長雲. "Guanyu Xiadai guojia chansheng de ruogan lilun yu shizheng wenti 關於夏代國家產生的若干理論與實證問題 [Some Theoretical and Evidential Issues Regarding State Formation in the Xia Period]." Zhongyuan wenhua yanjiu 中 原文化研究, no. 1 (2015): 5-13.

Shen Changyun 沈長雲. "Lun Yu zhi hongshui zhenxiang jian lun Xia shi yanjiu zhu wenti 論禹治洪水真象兼論夏史研究諸問題 [On the Veracity of Yu's Taming of the Floods and Some Issues Pertaining to Research into the History of the Xia].” Xueshu yuekan 學術月刊, no. 6 (1994): 71-77.

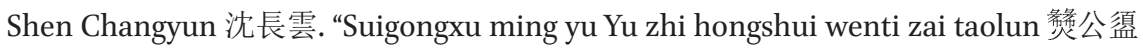
銘與禹治洪水問題再討論 [On the Suigongxu Inscription and Yu's Taming of the Floods]." Guoxue xuekan 國學學刊, no. 1 (2014): 49-61, 143.

Shen Changyun 沈長雲. "Xiadai shi duzhuan de ma: yu Chen Chun xiansheng shangque 夏代是杜撰的嗎一與陳淳先生商榷 [Is the Xia Period a Fabrication? A Discussion with Mr Chen Chun]." Hebei shifan daxue xuebao (zhexue shehui kexue ban) 河北師 範大學學報 (哲學社會科學版), no. 3 (2005): 89-96.

Shen Changyun 沈長雲 and Zhang Weilian 張渭蓮. Zhongguo gudai guojia qiyuan yu xingcheng yanjiu 中國古代國家起源與形成研究 [Research on the Origins and Formation of the Ancient Chinese State]. Beijing: Renmin chubanshe, 2009.

Shen Jianhua 沈建華. “Qinghua chujian yinzhi shiwen shijie 清華楚簡〈尹至〉釋文試 解 [Explanation of the Yinzhi Article's Translation in the Qinghua Bamboo Slips].” Zhongguoshiyanjiu 中國史研究, no. 1 (2011): 67-72.

Sun Qingwei 孫慶偉. Ding zhai yu ji: Xiadai xinshi de kaoguxue chongjian 躬宅禹 跡: 夏代信史的考古學重建 [The Trace of the Yu in the Ding House: Archaeological Reconstruction of the True History of the Xia Dynasty]. Beijing: Sanlian shudian, 2018.

Tan Jihe 譚繼和. “Xia Yu wenhua de xin tansuo: jinnian lai Xia Yu wenhua yanjiu shuping 夏禹文化的新探索一近年來夏禹文化研究述評 [New Explorations of Xia Yu Culture: Reviews on the Latest Research on Xia Yu Culture]." Zhonghua wenhua luntan 中華文化論壇, no.1 (2000): 57-61.

Tan, Liangcheng, Chuan-Chou Shen, Yanjun Cai, et al. "Great Flood in the MiddleLower Yellow River Reaches at 4000 a BP Inferred from Accurately-Dated Stalagmite Records." Science Bulletin 63, no. 4 (2018): 206-8. 
Thorp, R. L. China in the Early Bronze Age: Shang Civilization. Philadelphia: University of Pennsylvania Press, 2006.

Wang Guowei 王國維. Gushixinzheng: Wang Guowei zuihou de jiangyi 古史新證一王 國維最後的講義 [New Criticisms of Ancient History: Notes on Wang Guowei's Last Lecture]. Beijing: Qinghua daxue chubanshe, 1997.

Wang Yuxin 王宇信. “Meiguo Xia wenhua guoji yantaohui ceji 美國 “夏文化國際研 討會' 側記 [Notes on the International Symposium on Xia Culture Held in the United States]." Zhongguoshi yanjiu dongtai 中國史研究動態, no. 8 (1990): 22-29.

$\mathrm{Wu}$ Qinglong, Zhao Zhijun, Liu Li, et al. "Outburst Flood at 1920 BCE Supports Historicity of China's Great Flood and the Xia Dynasty." Science 353, no. 6299 (2016): $579-82$.

XieWeiyang 謝維揚. “Gushu chengshuheliuchuan qingkuangyanjiu dejinzhanyugushi shiliaoxue gainian: wei jinian gushi bian di yi ce chuban 80 zhou nian er zuo 古書 成書和流傳情況研究的進展與古史史料學概念一為紀念〈古史辨〉第一冊出版 80 週年而作 [Progress Made in Research into the Formation and Circulation of Ancient Texts and the Concept of Ancient Chinese Documentology: In Commemoration of the 8oth Anniversary of the First Volume of 'Gushi Bian']." Wen shi zhe 文史哲, no. 2 (2007): 47-54.

Xie Weiyang 謝維揚. "Shui shi Lushan zhenmianmu: Jianqiao Zhongguo shanggushi duhou 誰識盧山真面目：〈劍橋中國上古史〉讀後 [Who Can Recognize the True Face of Mount Lu? Impressions on The Cambridge History of Ancient China]." Wen huibao 文匯報, April 21, 2001.

Xu Hong 許宏. “Guanyu erlitou wei zaoshang duyi de jiashuo 關於二里頭為早商都 邑的假說 [Hypothesis about Whether Erlitou Is the Capital of the Early Shang Dynasty]." Nanfang wenwu 南方文物, no. 3 (2015): 1-7+22.

$\mathrm{Xu}$ Xusheng 徐旭生. Zhongguo gushi de chuanshuo shidai (xiudingben) 中國古史的 傳說時代 (修訂本) [The Legendary Period in Ancient Chinese History]. Beijing: Wenwu chubanshe, 1985 .

Yang Kuan 楊寬. “Shuo Xia 說夏 [On the Xia].” In Zhongguo shanggushi daolun 中國 上古史導論 [Introduction to Chinese Ancient History], 185-205. Shanghai: Shanghai renmin chubanshe, 2016.

Zhang Guoshuo 張國碩. “Lun Xia wangchao cunzai de yiju 論夏王朝存在的依據 [Evidence for the Existence of the Xia Dynasty].” Zhongguo lishi wenwu 中國歷史 文物, no. 4 (2010): 58-66.

Zhang Guoshuo 張國碩. “Shixi Xia wangchao fouding shuo xingcheng de yuanyin 試 析“夏王朝否定說”形成的原因 [A Tentative Analysis on the Contributing Factors behind Xia-Dynasty Denial]." Huaxia kaogu 華夏考古, no. 4 (2010): 90-95.

Zhang Guoshuo 張國碩. “Zhoudai duzhuan Xia wangchao shuo kaobian 周代杜撰 “夏王朝說” 考辨 [Testing the Theory That the Xia Dynasty Was Fabricated in the Zhou Period]." Zhongyuan wenwu, no. 3 (2010): 46-50. 
Zhang Jingwei 張經緯. “Da Yu he qianli zhi wai de hongshui 大禹和千里之外的洪水 [Yu the Great and the Flood Thousands of Miles Away]." Wenhui bao 文匯報, Aug 12, 2016, 2.

Zhao Ping'an 趙平安. “Houfu de xingzhi jiqi yunhan de xiadai lishi wenhua 〈厚父〉的 性質及其蘊含的夏代歷史文化 [The Nature of the Houfu Article and Its Historical and Cultural Characteristics of the Xia Dynasty]." Wenwu 文物, no. 12 (2014): $81-84,88$. 